\title{
An integrated approach to economic and community development*
}

\author{
JEFF TROON \\ Southland District Council, PO Box 903, Invercargill \\ jeff.troon@southlanddc.govt.nz
}

Keywords: crops, climate, economic development, forestry, soils, tourism

\section{Executive summary}

Over the past 10 years, the Southland District Council has developed a proactive integrated approach to economic development. The approach has developed in response to identified needs and opportunities.

The strategy recognises the importance of quality recreational opportunities, local services, amenities and infrastructure in the retention of population and attraction of new residents. These are seen as being complementary to initiatives targeted at producing increased employment opportunities.

Regional initiatives are undertaken with other authorities or organisations where appropriate, and include:

- Tourism Southland

- Regional Identity - Branding

- Crops for Southland

- Topoclimate

- Enterprise Connections.

A close working relationship and accountability to local communities is maintained through elected members. These include the Mayor, Councillors and 12 Community Boards and 16 Community Development Area Committees.

Concept development plans, prepared in conjunction with local communities, provide the basis for identifying local aspirations and priorities and linking these, where appropriate, to regional initiatives to ensure an integrated approach is achieved.

A project-based approach and working with groups or organisations with a clear focus and expertise relevant to the project or issue, ensures effective use of resources and the achievement of positive outcomes.

\section{Introduction}

The Southland District Council's strategy for economic development has evolved over the past 10 years since the formation of the District in November 1989.

The strategy reflects the key factors relevant to the District including geography, demographics, community and representative structure as well as current and projected external influences.

The strategy is based on a proactive and integrated approach at both regional and local levels. A projectbased approach has been adopted to provide a clear focus, accountability and credibility through the involvement of elected and community representatives.

\section{Background}

The Southland District covers a large and diverse geographic area of $30753 \mathrm{~km}^{2}$ including Fiordland World Heritage National Park and Stewart Island.

The population of 30532 (1996 Census) is based on 30 small communities scattered throughout the District. The two largest communities being Te Anau (1780) and Winton (2191).

A major priority of the District Council is local involvement in decision-making, which is achieved through 12 Community Boards and 16 Community Development Area Committees. These are in addition to the Mayor and 12 Councillors elected from wards in the District. This structure provides a high level of credibility and accountability for staff involved in economic and community development initiatives.

Council's vision outlined below reflects the importance of infrastructure, a quality environment and quality of life to residents and forms the basis of the approach to economic development.

\section{Southland District Council Vision}

- A progressive and innovative District with excellent infrastructure.

- A range of industry creating sustainable employment opportunities in a quality environment.

- A population of 40000 people based in thriving communities.

- Local services and recreational amenities, which provide a good quality of life for residents.

\footnotetext{
Excerpts from a full, integrated development paper prepared February 2000.
} 
The relevance of Council's approach including infrastructure, quality of life and environmental sustainability as integral elements of effective economic development was reinforced by a presentation by McKeogh at a conference in 1999 (the leader of Sydney's successful bid for the Sydney Olympics and currently leading development of a 20 -year economic strategy for Sydney).

In developing the Council's strategies the following threats to rural communities were identified:

- Withdrawal of services

- Urban drift

- Lack of employment

- Decline in health services

- Loss of skills

- Reliance on commodity trading

- Intergenerational issues - farms

A study commissioned by Butcher and Associates indicated projected decline in population and employment in the District through 2000-2011. The main cause of the decline assessed by Butcher was the introduction of technology in traditional industries such as freezing works and service sectors.

Council has developed a range of strategies to offset and counter the decline projected by Butcher.

\section{Southland District - Employment}

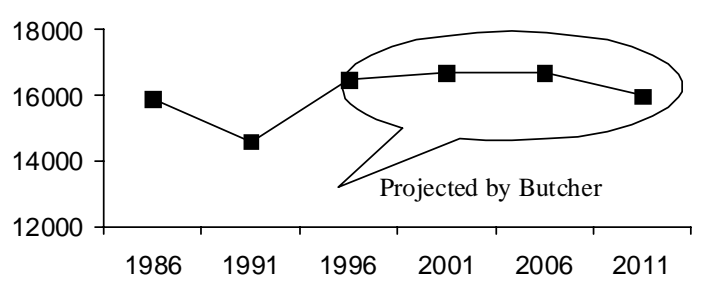

Southland District - Population

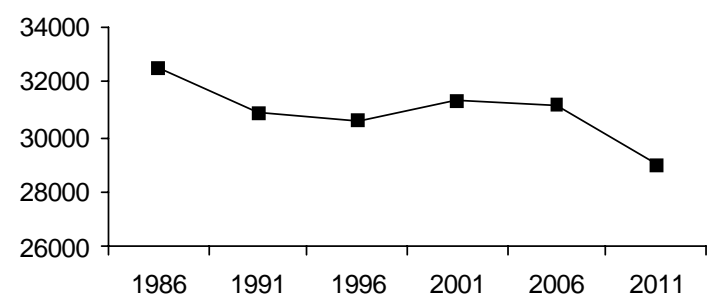

\section{Strategies}

Council's approach is divided into three broad strategies, which are complementary and integrated at regional, district, and local levels.

\section{- Tourism and promotions}

Recognising the potential of the natural attractions of the District along with the growing trend in ecotourism and free independent travellers.

\section{- Community development}

A proactive approach to retention of services and developing quality amenities and programmes to preserve and enhance the quality of life of residents.

- Enterprise development

A proactive approach to identifying opportunities for diversification, adding value and new initiatives to provide additional sustainable employment opportunities.

The above approaches are complementary to and supported by Council's core activities of maintaining a high quality infrastructure and a quality sustainable environment.

\section{Concept Development Plans}

Concept Development Plans have been prepared for most of the communities in the Southland District. This process, based on community input, ensures local buy-in and ownership, effective use of resources and coordinated development. The implementation of Concept Plan projects is coordinated by a steering committee. Southland District Council staff provide ongoing advice, support and practical assistance when required. The community initiatives and priorities are incorporated in district and regional strategies where appropriate.

Concept development plans incorporating local ideas have resulted in a range of local initiatives for amenities, services and enterprise opportunities.

Examples include:

- Locator Beacons

- Hump Ridge Track

- Festival of the Horse

- Backpackers Hostel

- Living Fiordland Wildlife Park

\section{Enterprise development}

Enterprise development (the identification of opportunities to establish or expand industry or enterprises which provide sustainable employment opportunities compatible with the natural environment) is obviously a key part of Council's overall economic development strategy.

Council has been proactive in establishing and developing initiatives in this area, which offer 
significant potential for diversification and employment. Key aspects of Council's approach are:

- Diversification

- Identification of opportunities

- Value added

- Business advice

- Compatibility with local social and natural environments

The efforts are based on three distinct but complementary initiatives:

- Crops for Southland

- Topoclimate

- Enterprise Connections

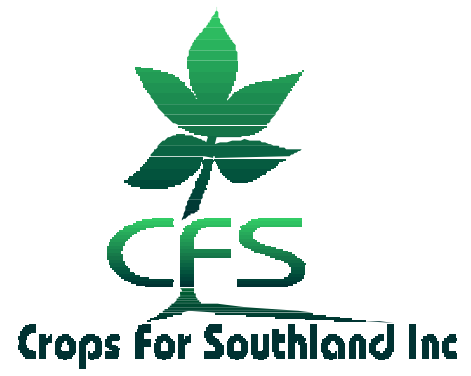

The Crops for Southland initiative evolved from 1990 when a need for diversification was identified as an opportunity for traditional farmers to achieve supplementary income, and derive income from lifestyle blocks.

To assess the level of interest in floriculture and horticulture a number of seminars were held. Attendances between 200 and 400 indicated the merit of pursuing this initiative.

A book "Cool Climate Flowers" was produced containing experiences of a number of established local growers, information on prospective varieties of flowers suitable to Southland, and on propagating and marketing. The book was extremely successful and required a second reprint and a second edition is now being considered.

A need for research to make information available to prospective growers was identified. The Crops for Southland Incorporated Society was formed for this purpose. The objectives are to identify competitive crops for Southland and instigate research utilising government grants. Up to 80 potential flowers and crops have been identified with specific research being carried out on 35 to date.

The research, starting with a desk assessment, focuses on three key aspects - marketing, processing and growing - all essential elements for a successful venture.

Some key crops that have proved successful are:

- Peony

- Gentians

- Ginseng

- Wasabi

- Meadowfoam

An example of the potential of this approach is demonstrated on a Northern Southland farm. Two hectares were converted to peonies in 1995 . The income from the peonies now exceeds that of the balance of the 160-hectare traditional sheep farm. The farmer, his wife and two sons are now employed on their peony project with a manager employed to run the farm.

The successful development of the Crops for Southland project led to the establishment of a new crop centre for research, trials and communication of the technology transfer to potential growers through seminars.

The need for additional information on soils and local climates to complement the trials and research into crops led to the major new complementary initiative - Topoclimate.

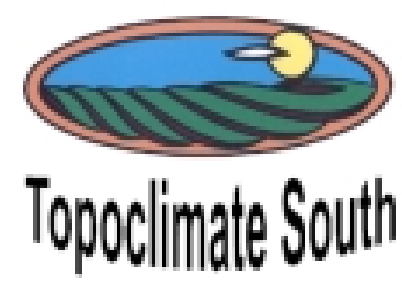

The Topoclimate initiative aims at carrying out research to establish detailed climate and soil mapping.

The project involves the detailed mapping of soils and local climate over approximately 800000 ha of Southland and South Otago at a total cost of $\$ 4.25$ million. The 3-year research project has received $60 \%$ of its funding from Community Trust of Southland, Southland District, Invercargill City, Gore District, Clutha District and Environment Southland. Contributions and partnerships have been sought from central government and research agencies for $40 \%$ of the project.

Some of the projected benefits include:

- Risk assessment

- Increase production by existing farmers

- Sustainability with better management practices 
- New crop opportunities - share cropping

- Diversification - employment

How much land could be expected to change to intensive horticultural use? The potential from diversification and job creation conservatively estimated from the Netherlands experience is:

- 805000 ha planned for survey in project

- One new job is created for each
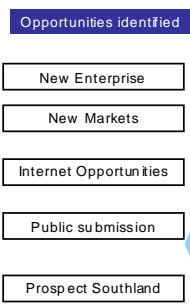

Prospect Southland

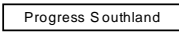

Focus Southland

Crops for Southland
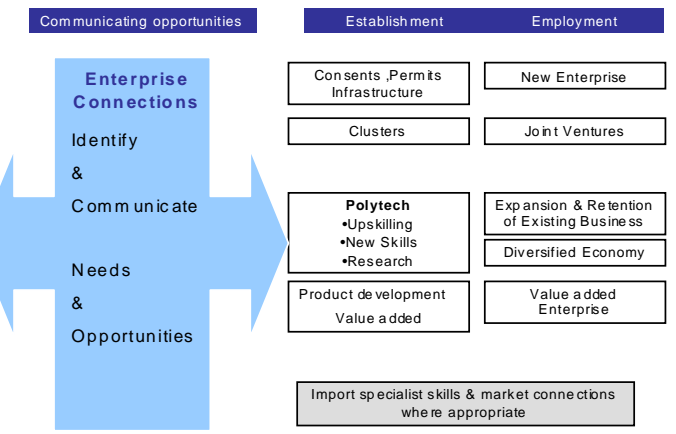

Value a dded

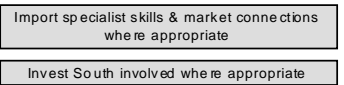

Interaction Facilitation

- In addition, up to four new jobs are created downstream

- If only 5000 ha were converted $(0.58 \%) \mathbf{2 0} 000$ jobs could be created

Following major interest from farmers, the potential benefits for better land use and management for traditional farming could well exceed those anticipated for diversification. An early example of some of the benefits is illustrated where traditional treatment had lead to significant differences in the growth of the crop in the same paddock. Topoclimate research indicates different soil types. Refencing the property relative to soil patterns would offer significant benefits to management and production.

The initial Topoclimate information will be available free of charge to property owners. More detailed technical information and assessments will be available at a fee through a bureau currently being established.

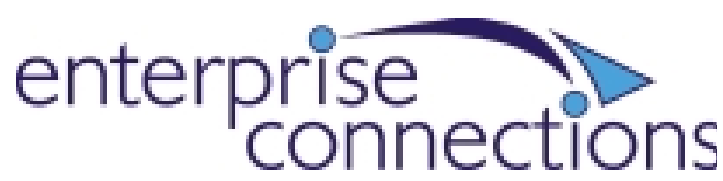

The most recent initiative commenced in December 1999 following a request from the Invercargill City Council to take over an extensive business database.

The initiative is proactive, project orientated and based on close direct contact with various business sectors communicating opportunities, identifying needs and facilitating outcomes.

The Southland District Council manages the initiative, with funding provided by the District, Invercargill City Council, Community Trust of Southland and Southern Institute of Technology.

The initiative provides a key link to assessing and establishing new opportunities, markets, joint ventures and clusters. It also provides advice and facilitates training and up-skilling where required.

Direct access to a range of databases listed below, including a detailed economic profile to assess and communicate opportunities, will be a basis for the initiative.

\section{Access \& assess databases}

- Business Link

Network

- TRADENZ Bulletin Board

- Business Link Database

- Supermap - Demographics - Topoclimate

- Geographical Information Data Systems

Southland economic profile content

- A. Generic Economic Profile

- B. Detailed Sector Profiles
1. Agriculture
2. Forestry
3. Fishing
4. Manufacturing
5. Tourism

- C. Opportunities

- D. Economic Monitoring

Direct contact with individual businesses on a confidential basis will allow needs to be met by direction to free advice through a range of programmes accessing professional expertise.

\section{Direct contact needs}

Business advice Business problems Specialist advice Training/up-skilling
- Mentors

- Company Rebuilders

- Talent Bank

- Institute of Technology 
New Markets:

Business Link

TRADENZ

Prospect Southland

Internet

Direct contact will also be used to communicate opportunities with particular emphasis on value-added products, joint ventures and servicing opportunities.

\section{Direct contact opportunities}

- Targeted business sectors

- Clusters - Alliances

- Joint ventures

- Servicing opportunities

- Added value - Industrial design

- Business assessments

- Blockages to growth - Progress Southland

- Brand involvement - Regional identity

An initiative being considered with the Southern Institute of Technology is the establishment of a joint venture industrial design/industry partnership aimed at adding value and employment opportunities based on the region's production of materials and natural resources.

Several cluster opportunities are currently being pursued, these include:

- Classic car cluster

- Forestry added value

- Film attraction cluster

- Southern bulb investment project

The approach being taken by the Southland District Council, in working closely with communities on projects and priorities which reflect the local social and natural environment, can be seen as a model which meets the objectives of the current government. This is reflected in support from Central Government in contributing \$1.8 million towards the Topoclimate initiative and $\$ 900000$ towards the Hump Ridge Track Project based at Tuatapere. 
